\title{
IMPACT OF COVID-19 ON THE OVERALL SECTOR OF BANGLADESH ECONOMY: AN OVERVIEW
}

\author{
Marina Akter \\ Lecturer \\ Department of Islamic Studies \\ Faculty of Social Science \\ Leading University, Sylhet-3112, Bangladesh \\ E-mail: marina.economics17@gmail.com
}

\begin{abstract}
After being affected by the Covid-19, Bangladesh also faces challenges related to this pandemic like other countries globally. The impact was spreading to all sectors of the economy. The principal purpose of this study is to give an overview of the pandemic's impact on the economy as a whole and summarize recommendations for mitigating the pandemic's devastating effects. This study employs descriptive and exploratory techniques based on secondary data collected from journals, newspapers, published articles, websites, and the internet. The discussion result reveals that, more or less, all the sectors of the economy are affected by the Covid-19 pandemic, not only public health. The study found that Manufacturing industries face losses, and workers are also affected by the various uncertainties about their earnings and job security. The country's education industry has been hit hard. In a new typical circumstance, students are unsure about studying and are concerned about the academic delay. The Covid-19 pandemic has had an impact on the mental health of students as well as the general public. The study recommends that the government's intervention, in conjunction with the engagement of relevant sectoral stakeholders, has the potential to recoup losses and design a new strategy or solution to address the problem.
\end{abstract}

Keywords: Covid-19, Coronavirus Pandemic, Sectoral impact on Economy, Manufacturing Industry, Education, Employment, Agriculture.

JEL Classification Codes: E71, A31, F6, I1.

\section{INTRODUCTION}

SARS coronavirus 2 (SARS-CoV-2) is a new coronavirus associated with severe acute respiratory syndrome. It was initially identified from three persons who had contracted pneumonia as a result of the Wuhan cluster of acute respiratory disease cases. Wuhan, the capital of central China, is the most populous city. Coronavirus disease (COVID-19) is a virus-borne infection caused by the SARS-CoV-2 viral. COVID-19 was declared a global pandemic on March 11, 2020 by the World Health Organization (WHO).Bangladesh was recently recommended as a developing country by the World Bank for the year 2026. The covid-19 
outbreak and the world economy's downward trend cannot be a hindrance to accomplishing the objectives. While the rest of the world is facing an economic decline as a result of the COVID19 epidemic, Bangladesh's economy has escaped a 2020 contraction. According to a forecast by the Asian Development Bank, the country's yearly GDP growth rate would continue to rise between 2021(5.5\%) and 2022(6.8\%) (Asian Development Outlook Update (ADOU), Serptember2021). However Kumar \& Pinky, (2020) found that with the impact it has had on the country's social, economic, and health sectors, the COVID-19 epidemic has slowed GDP growth and contributed to rising poverty, inequality, and unemployment across the country.

The world economy has been severely harmed, and practically every country has seen the detrimental impact of Covid-19. Global economic growth was badly harmed in the first half of 2020, and the global economic growth prediction for 2020 was -4.9 percent. (World Economic Outlook update, June 2020).It has been noticed that any pandemic has a multiplicity of effects on the planet, with long-lasting consequences. Researchers have evaluated the impact of COVID-19 on a variety of sectors and discovered that the unemployment rate has risen due to the corona pandemic.

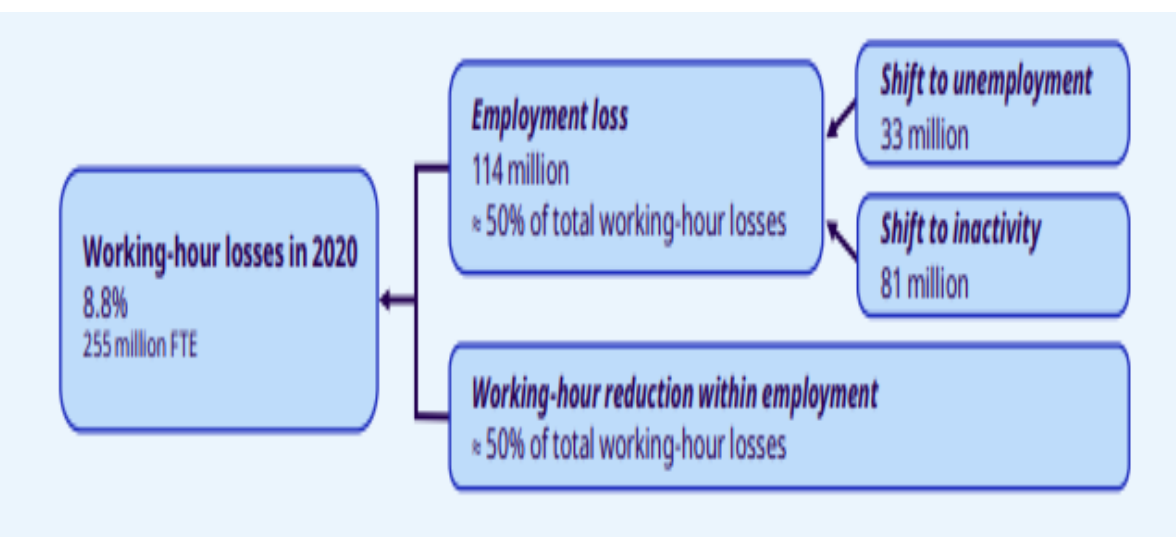

Figure 1. Estimates of the working hours and employment loss in 2020 Source: ILO Monitor, January 25, 2021

This pandemic has had severe adverse effects on the Turkish economy's employees, customers, supply chains, and financial markets. With the high unemployment rate, the CPI of Turkey increased by $11.86 \%$ annually and $0.57 \%$ monthly in March 2020. Turkey's Economic Confidence Index fell from 97.5 to 91.8. A higher CDS premium might cause pressure on the Turkish foreign borrowing interest rate to rise (Açikgöz \& Günay, 2020).Because of Covid-19, (Thorbecke, 2020) identified idiosyncratic factors that harmed airlines, aerospace, real estate, tourism, oil, breweries, retail apparel, and funerals. Additionally, he discovered that macroeconomic factors contributed to losses in sectors such as manufacturing equipment, machinery, and electronic and electrical equipment in the USA economy. Like other countries Bangladesh also affected by the coronavirus pandemic.

This study will focus on the issue of how the coronavirus pandemic affects the different economic sectors and social life of Bangladesh.

\section{METHOD}

The nature of this study is both descriptive and exploratory. Secondary data were gathered from a variety of sources, including journals, newspapers, published articles, the news media, the 
internet, the websites of the World Health Organization (WHO) and the Government of Bangladesh (GoB), as well as data from other surveys and research.

\section{COVID-19'S SECTORAL IMPACT (RESULTS AND DISCUSSION)}

The impacts of covid-19 on various sectors will be discussed in this section. The discussion will be based on secondary data gathered from a variety of different sources.

\section{Impact on Agriculture Sector}

BRAC Institute of Governance and Development found that COVID-19 reduced the estimated 2020 yield of Boro rice by seven percent, amounting to BDT 3,687 crore in lost revenue for the country. Low demand and reduced production combined with high input prices resulted in a $40 \%$ loss for Boro growers in 2020. According to Bashar and Atik (2020), around 350,000 dairy farmers in Bangladesh are attempting to escape the coronavirus epidemic by not selling about 27,000 tons of milk per day. It was discovered by (Zabir et al., 2021) research that insufficient monitoring systems, employment losses, and constrained transportation are the major obstacles to the nation's ability to meet its food needs. The lockdown drastically restricts the farming community's movement, mostly hurting farm laborers, who must generally move from job to job in order to earn a wage. Numerous concerns associated with COVID-19 consequences were identified in the survey findings, including loss of labor mobility, rising labor costs, restricted transportation, loss of food security and dietary diversity, decreased incomes, and increased consumer uncertainty (Shoaib \& Arafat, 2020).

To address the pandemic's impact on agriculture, the Bangladesh government has already allotted Tk 100 crore to the agricultural ministry for the mechanization of crop harvesting. Additionally, the government will allocate another Tk 100 crore in this direction (The Daily Star, April 13, 2020)

"Bangladesh Bank will formulate a new refinancing scheme of Tk 5,000 crore to pump running capital into the agricultural sector. We'll create this Tk 5,000 crore stimulus package only for the agricultural sector. We'll disburse money from this fund among farmers at only 5 percent interest," (Prime minister Sheikh Hasina)

The following actions or recommendations need to implement:

- More incentives are needed to encourage innovative research and activities that increase productivity, minimize production losses, and boost value-added activities in agriculture and non-agricultural businesses. There is a need for further research and activities related to improving the design of financial technologies for farmers and encouraging more participation in these economic systems such loans and credit systems, agricultural insurance facilities, etc. Policies and initiatives that encourage culturally appropriate institutional and organizational interventions (Gregorio \& Ancog, 2020).

- In terms of policy, it's clear that: Continued supply chain monitoring and industry involvement are required. The proactive creation of solutions to cope with absenteeism and other supply chain risks and the assessment of the economic and health benefits of giving more public resources to offer wider access to food pickup and delivery services. (Gray, 2020)

- Poudel P. B. et al. (2020) vision is centered on sustaining and improving supply chain resilience. The government should enact pandemic-control measures that do not disrupt 
the food supply chain and do not jeopardize their citizens' food security. COVID-19 and its Global Impact on Food and Agriculture.

- (Varshney, Kumar, Mishra, Rashid, \& Joshi, 2021) discovered that the farmers benefitted from the emergency assistance package. Direct cash transfers are used by 8994 percent of families. In India, a minimum income support program that provides cash transfers to farmers enhanced small and marginal farmers' seed purchases during the cropping season.

\section{Impact on Manufacturing sector}

After China, Bangladesh boasts the world's second-largest clothing industry. It makes almost \$35 billion annually from exports to the US and Europe and employs roughly 4 million people, mostly rural women. The garment sector generates 84.21 percent of total exports and 20 percent of GDP for the country (Antara, 2020). The pandemic canceled or suspended almost $\$ 3$ billion in orders, according to Bangladesh Garment Manufacturers and Exporters Association President Rubana Huq (Aslam, 2020).

Workers in the RMG industry are also affected by anxiety about the future of their careers because of the uncertainty surrounding it. Reports of rapes and suicide instances among female RMG employees during the COVID-19 epidemic might have long-term effects on their mental health (Kabir, Maple, \& Usher, 2021).

Due to a lack of raw resources, manufacturers must cease operations. A survey found that 93\% of Bangladeshi garment producers experienced delays in raw material supplies due to the epidemic. A survey revealed that $72.4 \%$ of Bangladeshi firms couldn't pay their workers when they were furloughed. When orders were cancelled and workers were fired, over $80.4 \%$ of Bangladeshi suppliers said they couldn't compensate them (Anner, 2020).

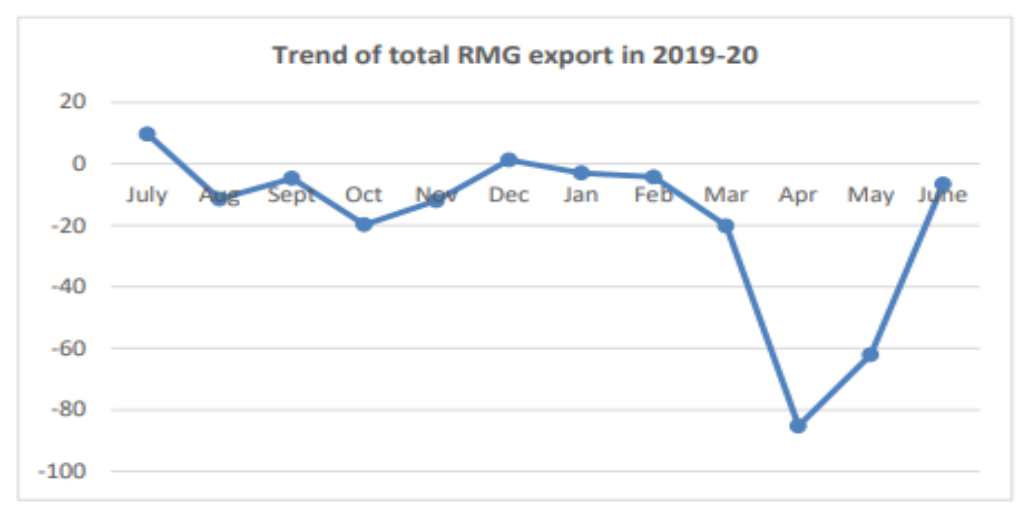

Figure 2. Trend of total RMG export in 2019-20

Source: Prepared by (M.R.Islam, et al. 2020)

Table 1. Impact of COVID-19 on RMG factors

\begin{tabular}{|l|l|l|}
\hline Factory reported & Export cancelled & Workers affected \\
\hline 1,150 & 3.18 billion USD & 2.28 million \\
\hline
\end{tabular}

Source: Majumder, 2021 
Figure 2 illustrate the scenario of impact on RMG (Readymade Garment) export due to pandemic. Export decrease dramatically from March to April 2020. About 2.28 million workers of RMG sector are affected (Table 2).

To protect employees' health and general wellbeing during the COVID-19 pandemic, global health communities, BGMEA, international brands/retailers, the GoB, and the International Labour Organization (Kabir et al., 2021)suggest immediate coordinated and effective efforts by all parties.

\section{Impact on Education}

The proliferation of coronavirus, which has caused several problems, has prompted many countries to close their educational institutions. The coronavirus pandemic has had a profound effect on education and public health. A study conducted by Salmi, Arnhold and Bassett (2020) found Limited resources and poor infrastructure have made it impossible for governments in many developing countries, like Bangladesh and Nepal, to make the change smoothly.

According to Biswas et al. (2020), the majority of university students have a favorable attitude toward mobile learning. This study established that mobile learning is extremely beneficial for resolving study gaps during this COVID-19 pandemic period.

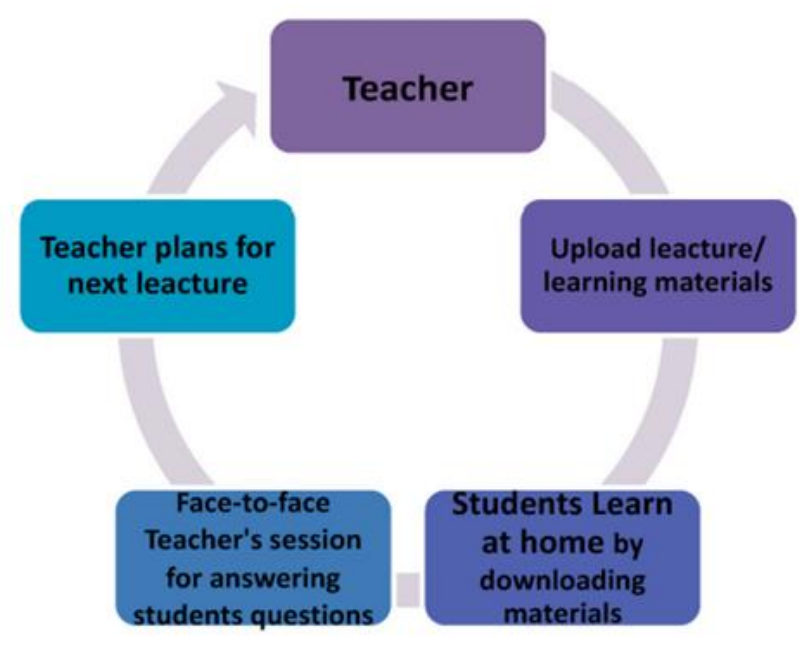

Figure 3. Flipped classroom activities Source: Khan and Abdou (2021)

Khan and Abdou (2021) offer a flipped classroom idea through which during the COVID-19 epidemic, developing nation's higher education institutions can continue teaching and learning without spending money or planning training.

In an online course, increased engagement improves the overall performance level. According to research, increasing the amount of debate between students and teachers can lead to better interactivity (Townsend et al., 2002). Students' participation in lectures can be boosted by allowing them to take part in online classes. In addition, students may be more engaged if they discuss and ask questions about case studies (Smith \& Diaz, 2004). 


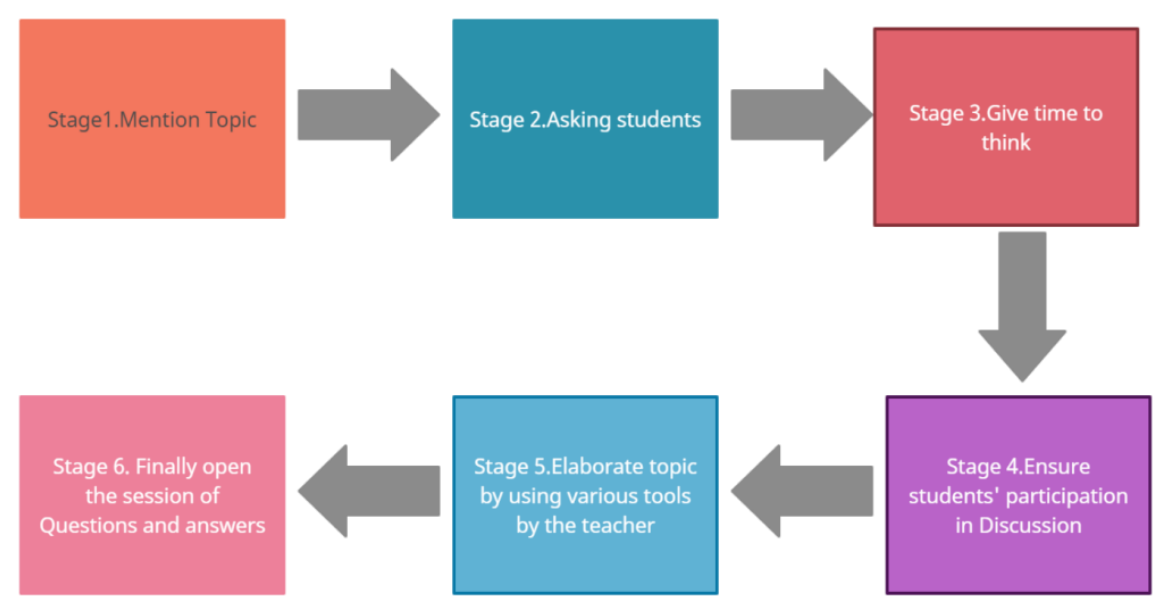

Figure 4. Interactive online class during Covid-19

According to figure 4, a teacher can introduce any course topic using six steps. It assists students in overcoming monotony and increasing their excitement for online classes. After mentioning any case, the teacher may inquire the pupils about their familiarity or unfamiliarity with the subject. They are given a few minutes to gather their thoughts to contribute to the conversation. At stage 5, the teacher can explain the topic using their preferred way. Finally, following a threadbare discussion, the course instructor will conduct a question and answer session.

Meo, Abukhalaf, Alomar, Sattar, \& Klonoff (2020) mention that as a result of the extended home confinement, students' study habits and work performance deteriorated, leading to increased stress and dysfunctional learning practices. Job instability was discovered in a survey of 100 private education sector employees conducted by (Imran \& Ahmed, 2020). The majority of private educational institutions rely on their own revenue from student tuition fees; hence, the difficulty in managing them during the stalemate condition and their staff are also in financial difficulty. Just around 25\%-30\% of private sector educational institutions offer online courses; the remainder are at a standstill. Numerous kindergartens, schools, and universities have ceased operations entirely owing to the pandemic scenario. They are unable to pay their staff for six months. (Imran \& Ahmed, 2020).

Financial factors had a significant impact on student's mental health and academic performance: students lost tuition or part-time jobs, were unable to afford new online classes, parents' income decreased due to the COVID-19 pandemic, and students dropped out of the academic year or semester due to a lack of funds (Dutta \& Smita, 2020). Students at Bangladeshi universities have been suffering from immeasurable psychological stress symptoms as the dread of academic delay has progressed throughout the COVID-19 period, which is very clear (Hossain et al., 2021). A decrease in appetite, physical inactivity, weight gain or obesity, weakness, giddiness, weariness, and a sluggish sense are all symptoms of remaining at home (Dutta \& Smita, 2020). All of this hindered pupils' learning flow and deflated their excitement.

There are some recommendations related to education during Covid-19: 
- Universities should develop all-inclusive online educational programs in collaboration with internet service providers to reach students living in remote locations with or without gadgets. Moreover, parents should be urged to establish a welcoming and constructive home atmosphere for university students without placing pressure on future academic and professional careers (Islam, 2020).

- (Hossain et al., 2021) suggests that intense psychological treatment, economic stability, and seamless educational programs to close the academic gap must be maintained by joint efforts by the government, universities, and educators.

- Online class training and outcome-based education (OBE) can assist both employers and students overcome obstacles. Teleworking like online classes and exams help stabilize the financial condition, which is the major worry for the owner now. Employees can use teleworking to normalize this divide and avoid social isolation. (Imran \& Ahmed, 2020)

- Families, friends, and the government must all work together to reduce pupils' social, physical, emotional, and educational disturbances. It is advised that immediate efforts be made to provide technological resources and enhance internet connectivity in order to ensure that online education may continue uninterrupted in Bangladesh in order to meet the educational demands of tertiary level students (Dutta \& Smita, 2020).

\section{Impact on Employment}

Mr. Mostafiz Uddin, the Managing Director of Denim Expert Limited, predicted that a small number of clothing employees will lose their jobs as a result of the COVID-19 (Uddin, 2020, March 24).(Sakamoto, Begum \& Ahmed, 2020) observed that significant economic losses are unavoidable, and many garment sector workers may be unable to find work for a longer duration. Out of Bangladesh's 63 million employees, about 25 million earn a wage/salary, with over 10 million earning daily pay. Around 4.5 million casual workers in construction, transportation, trade, food and lodging were severely impacted by the Covid-19 (Islam, 2020)

Table 2. Employments under threat of being lost in the world

\begin{tabular}{|l|l|}
\hline Industry & No. of Employment in threat \\
\hline RMG & 10.5 million \\
\hline Dairy & 10.2 million \\
\hline Poultry & 5 million \\
\hline Transportation & 5 million \\
\hline Tourism & 1 million \\
\hline
\end{tabular}

Source: Shaminnta, Gope, and Sumaiya (2020)

Across industries, a large number of people may lose their employment. Although employees in the dairy, poultry, transportation, and tourist industries face job loss, it is the RMG business that faces the greatest job loss (Table 2).Furthermore, a sizable number of selfemployed workers, around 5.19 million self-employed workers in the urban informal sector, live in insecure circumstances (Islam, 2020)

Most RMG firms have decreased worker pay. If they regularize the pay, the workers may be more motivated. A minimal risk premium may be imposed for garment workers who contract 
COVID-19 or die from it. In this epidemic condition, 1-2 percent profit sharing with workers may be motivating (Islam, Hassan, Hassan, Rahman, \& Nargis, 2020).

\section{Impact on Social Life}

Various factors related to social life have a significant impact on economic well-being. So we have to find out the problems that are created by the covid19 to address them. Domestic violence such as child marriage, marital rape, and physical torture continuously increased during pandemics. There were 4,622 women emotionally tormented in June 2020, 1,839 physically assaulted, 203 sexually molested and 3,009 women who had financial limitations placed on them by their spouses. (Manusher Jonno Foundation, 2020).According to another study, 107 women were murdered by their spouses between January and June of 2020, but only 74 cases were reported. Members of the husband's family were responsible for the deaths of 30 women, while members of the wives' families were responsible for the deaths of 26 women. Only 33 of the individuals filed any claims (Ain o Salish Kendra, 2020).

(Mahmud \& Islam, 2021) discovered that social stigma is caused by disinformation, uncertainty, fear of responsibility, administrative failure, and a lack of faith in treatment. Additionally, their study demonstrates that stigma has a variety of negative consequences, including health risks, harassment, discrimination, life insecurity, psychological distress, loss of social and emotional capital, shattered family bonds, and social solidarity, all of which act as barriers to social well-being.

The internet has become vital in modern life, yet regular usage might harm one's physical and emotional health. Extra free time during pandemic may have caused ennui among internet users. Its overuse during the epidemic may have aided problematic internet usage behavior, as noted by (Islam et al., 2020). They discovered that people from nuclear families utilize the internet more than people from extended families.

There are some ways to overcome the problem in social life described by other authors are the following:

- It is strongly suggested that active surveillance and effective monitoring mechanisms be developed to help minimize the spread of disinformation via social and electronic media, as well as to enhance the state of mental health conditions during the pandemic (Hossain et al., 2020).

- To protect mental health from Covid-19, a Confident and satisfying living place and society can help (Rahman et al., 2021).

- To safeguard the health of older persons against covid-19, it is necessary to confirm the attitude of social care and health systems in ensuring welfare, promoting preventative measures, and facilitating access to healthcare (Hossain, Mazumder, Tasnim, Nuzhath, \& Sultana, 2020).

- It is essential to introduce a time-oriented policy and implement care monitoring plans in the country, which may help manage the pandemic and nurture public mental health to combat COVID-19 related psychological challenges (Islam, Bodrul-Doza, Khan, Haque, \& Mamun, 2020).

- Medical facilities such as testing, tracking, formal quarantining, and special treatment for coronavirus in coronavirus hospitals should be strengthened and decentralized to protect social stigma. This can be done by allocating significant state funds and also by implementing public-private partnership initiatives for health management (Mahmud \& Islam, 2020). 


\section{Impact on Tourism Sector}

To stop the virus from spreading, all governments have enforced lockdowns and limited travel. Tourism is linked to human movement, which is hampered by travel restrictions. Tourism in Bangladesh is slowly increasing due to a large domestic travel market. Due to the epidemic, both domestic and foreign visitors canceled. However, due to various travel restrictions, all flights have been canceled. As a result, businesses lose money and workers lose jobs (Deb \& Nafi, 2021). According to industry experts, over 4,000 million people are employed by tour operators, hotels, resorts, airlines, and food businesses that are currently fighting to stay afloat. According to a research released by the Tour Operators Association of Bangladesh (TOAB) in April 2021, the loss is expected to be Tk 57 billion by the end of 2020. The National Board of Revenue (NBR) received Tk 3.28 billion in travel tax during the previous fiscal year, less than half of the amount collected the year before. Tk 7.66 billion in travel tax was collected in FY 20. By 2021, air traffic would have decreased by $60 \%$, while the airline sector will have lost US $\$ 370$ billion due to the epidemic, according to an ICAO assessment released on January 15th (Mala, 2021).

Local residents who rely on visitors stated that they would be able to compensate for the closure's losses. According to the Rangamati Chambers of Commerce and Industry, travel operators together lost $\mathrm{Tk} 2.15$ crore. While the second wave of the epidemic was ravaging the country, the government authorized all tourist attractions, community centers, resorts, and places of leisure to reopen on August 19 with a 50 percent capacity and observe all Covid-safety standards (Dhaka Tribune, August 19, 2021).

COVID-19's effects on tourist employment place further strain on tourism education, which has been badly impacted by the pandemic. Apart from the virtualization of teaching and learning processes, tourism students and graduates must contend with the cessation of industry internships, recruiting, and dubious career options (Sigala, 2020).

\section{CONCLUSION}

Bangladesh is no stranger to international tragedies and disasters. Natural disasters and significant humanitarian crises are nothing new for Bangladesh. There is no comparison to the COVID-19 outbreak. Even though Covid-19's economic shock did not put the economy in jeopardy, the long-term impact from global uncertainty can nevertheless be highly damaging. And it requires an unprecedented plan to address the immediate threats of COVID-19 to all sector's long-term threats to the country's economy. The significant findings reveal that the industrial sector of the economy is mainly affected, and the agricultural industry is affected by a damaging supply chain. The employee, students, staff related to education are adversely oppressed. The unemployment problem is enhanced quickly. This report gives an overview of the pandemic's impact on the economy as a whole and summarizes recommendations for mitigating the pandemic's devastating effects. This analysis will help decision-makers to implement better plans and strategies to lessen the impact of pandemics on various economic sectors. An intervention by the government, along with participation from relevant sectorial stakeholders, might help recuperate costs and devise a new solution to the problem.

\section{FURTHER STUDY DIRECTION}

There is significantly little quantitative research found related to Covid-19. It is urgent to identify critical variables that make us unable to protect from the negative consequences of covid-19. Various econometric models can be used to find the correlation among the variables and shortrun, long-run effects of the variables on the economy. 


\section{REFERENCES}

Açikgöz, Ö., \& Günay, A. (2020). The early impact of the Covid-19 pandemic on the global and Turkish economy. Turkish Journal of Medical Sciences, 50(SI-1), 520-526. https://doi.org/10.3906/sag-2004-6

Islam, M. A., Barna, S. D., Raihan, H., Khan, M. N. A., \& Hossain, M. T. (2020). Depression and anxiety among university students during the COVID-19 pandemic in Bangladesh: A web-based cross-sectional survey. PLoS ONE, $15(8$ August), 1-12. https://doi.org/10.1371/journal.pone.0238162

Asian Development Outlook Update (ADOU). (September 2021). Economic indicators for Bangladesh. Retrieved from https://www.adb.org/countries/bangladesh/economy

Ain o Salish Kendra. (ASK). (2020). Violence Against Women - Domestic Violence Jan-June 2020. Retrieved from http://www.askbd.org/ask/2020/07/06/violence-against-womendomestic-violence-jan -june-2020/

Bashar, R., \& Atik, F. (2020). Dairy farmers hit hard by coronavirus lockdown in Bangladesh. Retrieved from https://bdnews24.com/banglades h/2020/04/13/dairy-farmers-hit-hardbycoronavirus-lockdown-in-bangladesh

Dhaka Tribune. (August 19, 2021). Bangladesh unlocks tourism. Retrieved from https://www.dhakatribune.com/bangladesh/2021/08/19/bangladesh-eases-restrictions-ontourism-as-coronavirus-rates-decline

Deb, S. \& Nafi, S. (2020). Impact of COVID-19 Pandemic on Tourism: Perceptions from Bangladesh. SSRN Electronic Journal. 10.2139/ssrn.3632798.

Dutta, S., \& Smita, M. K. (2020). The Impact of COVID-19 Pandemic on Tertiary Education in Bangladesh: Students' Perspectives. Open Journal of Social Sciences, 08(09), 53-68. https://doi.org/10.4236/jss.2020.89004

Das, D.N.C., Rahman, S., \& Islam, M.S. (2020). Protection and Revival of the Agriculture Sector From the COVID-19 Induced Economic Crisis. Brac Institute of Governance and Development. Retrieved from https://bigd.bracu.ac.bd/study/protection-and-revival-ofthe-agriculture-sector-from-the-covid-19-induced-economic-crisis/\#

Gray, R. S. (2020). Agriculture, transportation, and the COVID-19 crisis. Canadian Journal of Agricultural Economics, 68(2), 239-243. https://doi.org/10.1111/cjag.12235

Gregorio, G., \& Ancog, R. (2020). Assessing the Impact of the COVID-19 Pandemic on Agricultural Production in Southeast Asia: Toward Transformative Change in Agricultural Food System. Asian Journal of Agriculture and Development, 17(1), 1-14. https://doi.org/10.37801/ajad2020.17.1.1

Hossain, M. J., Ahmmed, F., Rahman, S. M. A., Sanam, S., Emran, T. Bin, \& Mitra, S. (2021). 
Impact of online education on fear of academic delay and psychological distress among university students following one year of COVID-19 outbreak in Bangladesh. Heliyon, 7(6), e07388. https://doi.org/10.1016/j.heliyon.2021.e07388

Hossain, M. M., Mazumder, H., Tasnim, S., Nuzhath, T., \& Sultana, A. (2020). Geriatric Health in Bangladesh during COVID-19: Challenges and Recommendations. Journal of Gerontological Social Work, 63(6-7), 724-727. https://doi.org/10.1080/01634372.2020.1772932

Hossain, T., Ahammed, B., Chanda, S. K., Jahan, N., Ela, M. Z., \& Islam, N. (2020). Social and electronic media exposure and generalized anxiety disorder among people during COVID-19 outbreak in Bangladesh: A preliminary observation. PLoS ONE, 15(9 September), 1-13. https://doi.org/10.1371/journal.pone.0238974

Imran, M. A., \& Ahmed, I. (2020). Job Insecurity in Private Education Sector Considering COVID-19 Pandemic: Bangladesh Panorama. American International Journal of Business and Management Studies, October, 41-51. https://doi.org/10.46545/aijbms.v2i2.245

Islam, M. R., Hassan, M. A., Hassan, M. S., Rahman, S., \& Nargis, N. (2020). Impact of Covid-19 Pandemic on Readymade Garments (Rmg) Industry of Bangladesh. International Journal of Management (IJM), 11(7), 1125-1132. https://doi.org/10.34218/IJM.11.7.2020.100

Islam, R. (2020). The impact of Covid-19 on employment in Bangladesh: Pathway to an inclusive and sustainable recovery. Bangladesh Institute of Labour Studies-BILS

Islam, S. M. D. U., Bodrud-Doza, M., Khan, R. M., Haque, M. A., \& Mamun, M. A. (2020). Exploring COVID-19 stress and its factors in Bangladesh: A perception-based study. Heliyon, 6(7), 1-10. https://doi.org/10.1016/j.heliyon.2020.e04399

ILO. (January 25,2021). ILO Monitor: Covid-19 and the world of work. Seventh edition.

Islam, M. S., Sujan, M. S. H., Tasnim, R., Ferdous, M. Z., Masud, J. H. B., Kundu, S., Mosaddek, A. S. M., Choudhuri, M. S. K., Kircaburun, K., \& Griffiths, M. D. (2020). Problematic internet use among young and adult population in Bangladesh: Correlates with lifestyle and online activities during the COVID-19 pandemic. Addictive Behaviors Reports, 12(July), 100311. https://doi.org/10.1016/j.abrep.2020.100311

Kabir, H., Maple, M., \& Usher, K. (2021). The impact of COVID-19 on Bangladeshi readymade garment (RMG) workers. Journal of Public Health (Oxford, England), 43(1), 47-52. https://doi.org/10.1093/pubmed/fdaa126

Khan, M. S. H., \& Abdou, B. O. (2021). Flipped classroom: How higher education institutions (HEIs) of Bangladesh could move forward during COVID-19 pandemic. Social Sciences \& Humanities Open, 4(1), 100187. https://doi.org/10.1016/j.ssaho.2021.100187

Mala, D.A. (July 15, 2021). Bangladesh's tourism industry devastated by Covid-19 fallout. The Financial Express. Retrieved from https://thefinancialexpress.com.bd/trade/bangladeshstourism-industry-devastated-by-covid-19-fallout-1626230592 
Manusher Jonno Foundation (MJF). (2020). Violence against Women and Children: COVID 19 A Telephone Survey: Initiative of Manusher Jonno Foundation Survey Period: June 2020. Retrieved from http://www.manusherjonno.org/wpcontent/uploads/2020/03/Final-Report-of-Telephone-Survey-on-VAW-June-2020.pdf

Mahmud, A., \& Islam, M. R. (2021). Social Stigma as a Barrier to Covid-19 Responses to Community Well-Being in Bangladesh. International Journal of Community Well-Being, 4(3), 315-321. https://doi.org/10.1007/s42413-020-00071-w

Shaminnta, L., Gope, H., \& Sumaiya, I. (2020). Readymade Garments Sector and Covid-19 in Bangladesh. June, 1-17. https://doi.org/10.20944/preprints202006.0336.v1

Majumder, F. H. (2021). Covid-19 and the RMG Industry: The Pandemic effect. The Apparel Story(JanuaryFebruary 2021). Bangladesh Garment Manufacturers and Exporters Association(BGMEA). Retrieved from www.bgmea.com.bd

Meo, S. A., Abukhalaf, A. A., Alomar, A. A., Sattar, K., \& Klonoff, D. C. (2020). COVID-19 Pandemic: Impact of Quarantine on Medical Students' Mental Wellbeing and Learning Behaviors. Pakistan Journal of Medical Sciences, 36, S43-S48. https://doi.org/10.12669/pjms.36.COVID19-S4.2809

Poudel, P.B., Poudel, M.R., Gautam, A., Phuyal, S., Tiwari, C.K., Bashyal, N., \& Bashyal, S. (2020). COVID-19 and its Global Impact on Food and Agriculture. Journal of Biology and Today's World, 9(5).

Rahman, M. M., Khan, S. J., Sakib, M. S., Chakma, S., Procheta, N. F., Mamun, Z. Al, Arony, A., Rahman, F., \& Rahman, M. M. (2021). Assessing the psychological condition among general people of Bangladesh during COVID-19 pandemic. Journal of Human Behavior in the Social Environment, 31(1-4), 449-463. https://doi.org/10.1080/10911359.2020.1848688

Sakamoto, M., Begum, S., \& Ahmed, T. (2020). Vulnerabilities to COVID-19 in Bangladesh and a reconsideration of sustainable development goals. Sustainability (Switzerland), 12(13), 1-15. https://doi.org/10.3390/su12135296

Shoaib, J. U. M, \& Arafat, M. F. (2020). IMPACTS OF COVID-19 ON AGRICULTURE IN BANGLADESH.Covid-19 - Dispatches from the Ground, WOCAT.

Salmi, J., Arnhold, N., \& Bassett, R. M. (2020, June 24). The big bad wolf moves south: How COVID19 afects higher education fnancing in developing countries. World Bank Blogs. Retrieved from https://blogs. worldbank.org/education/big-bad-wolf-moves-south-howcovid-19-afects-higher-educationfnancing-developing.

Smith, M., \& Diaz, A. W. (2004). Increasing students' interactivity in an online course. The Journal of Interactive Online Learning, 2(3), 1-26.

Townsend, E., Campbell, C., Curran-Smith, J., McGinn, F., Persaud, D., \& Peters, P. (2002). Accessibility and interactivity in distance education programs for health professions. 
Journal of Distance Education, 17(2), 1-24.

Thorbecke, W. (2020). The Impact of the COVID-19 Pandemic on the U.S. Economy: Evidence from the Stock Market. Journal of Risk and Financial Management, 13(10), 233. https://doi.org/10.3390/jrfm13100233

Unb, Dhaka. (April 13, 2020). Tk 5,000cr for farmers,PM unveils fresh stimulus package. The Daily Star. Retrieved from https://www.thedailystar.net/frontpage/news/tk-5000crfarmers-1892389

Varshney, D., Kumar, A., Mishra, A. K., Rashid, S., \& Joshi, P. K. (2021). India's COVID-19 social assistance package and its impact on the agriculture sector. Agricultural Systems, 189 (July 2020), 103049. https://doi.org/10.1016/j.agsy.2021.103049

World Economic Outlook update. (June, 2020). A crisis like no other, An uncertain Recovery. Retrieved from https://www.imf.org/en/Publications/WEO/Issues/2020/06/24/WEOUpdateJune2020

Zabir, A. Al, Mahmud, A., Islam, M. A., Antor, S. C., Yasmin, F., \& Dasgupta, A. (2021). COVID-19 and Food Supply in Bangladesh: A Review. South Asian Journal of Social Studies and Economics, 10(1), 15-23. https://doi.org/10.9734/sajsse/2021/v10i130252

\section{Copyrights}

Copyright for this article is retained by the author(s), with first publication rights granted to the journal. This is an open-access article distributed under the terms and conditions of the Creative Commons Attribution license (https://creativecommons.org/licenses/by/4.0/). 